Andrew Young School of Policy Studies Research Paper Series

Working Paper 08-15 July 2008

Department of Economics

Fiscal Research Center

\title{
The Property Tax Exemption for Nonprofits
}

\author{
David L. Sjoquist \\ Georgia State University
}

Rayna Stoycheva Georgia State University

This paper can be downloaded at:

http://aysps.gsu.edu/publications/2008/index.htm

The Social Science Research Network Electronic Paper Collection:

http://ssrn.com/abstract=1260297 


\title{
The Property Tax Exemption for Nonprofits
}

\author{
David L. Sjoquist \\ Rayna Stoycheva \\ Andrew Young School of Policy Studies \\ Georgia State University
}

July, 2008

This paper is forthcoming as a chapter in Nonprofit Economics and Management: The State of Research, edited by Bruce Seaman and Dennis R. Young and published by Edward Elgar. 


\begin{abstract}
This paper reviews the existing literature on the property tax exemption for nonprofit organizations and identifies gaps to be addressed in future research. We start by examining justifications and existing eligibility criteria for the property tax exemption, followed by studies of the magnitude of the revenue loss from the exemption. We focus on theoretical and empirical studies of the economic effects of the exemption. We consider the effect of the tax advantage on nonprofit decisions about inputs, outputs and organizational form, decisions to rent or own, location decision, market share, and the effect of the exemption on neighboring property values. Finally, we evaluate research about the use of PILOTs and the implications of their possible expansion. We conclude that future studies need to examine further the magnitude of the revenues forgone, the advantages and disadvantages of PILOTs, and other solutions for distributing more evenly the burden of the exemption. Further studies are also needed to understand the economic effects of the property tax exemption, with opportunities for theoretical and empirical contributions.
\end{abstract}




\section{Introduction}

The special tax treatment of nonprofits has been the subject of a substantial amount of writing. Empirical research on the effect of the tax treatment of contributions appears to far exceed the research on the analysis of the property tax exemption and the federal and state corporate income tax exemption. In this chapter we explore what we know and don't know about the property tax exemption. In summary, we know very little. There is very little theoretical work and even less empirical analysis of hypotheses regarding the effects of the property tax exemption.

In 1988, Weisbrod (1988) wrote, "Only a little is known about the quantitative importance of the various [tax] subsidies that are provided to nonprofits." While he was referring to the effect of tax subsidies on the size of the nonprofit sector, the statement was true for a broader range of issues. Twenty years later it does not appear that we know much more than we did then.

Much of what has been written about property tax exemptions focuses on the justification for the exemption. (See Rushton (Chapter 21 this book) for a discussion of the arguments for the exemption of nonprofits from corporate income taxes, the deduction of charitable donations from the personal income tax, and deduction of charitable gifts from the base of the estate tax.) Historically, nonprofit organizations have been exempt because they provided public services together with or in place of the government. Brody (2002) refers to this as the "sovereignty" justification for nonprofit exemption. In colonial times there was no explicit distinction between public and private 
provision of services as there is today, and the tax exemption of nonprofits was analogous to the tax treatment of other levels of government.

Another justification for tax exemption is based on the "subsidy theory". Hansmann (1987), for example, suggests that tax exemptions might be justified if there is a public policy reason to favor nonprofit firms, or if some market failure is addressed. This justification is the most economically compelling, but at the same time the approach to deliver the subsidy is questioned. There are no clear requirements about what is expected in return for this subsidy, just a general understanding that the exemption encourages activities that benefit the community. Also, this form of subsidy benefits organizations that own property, while smaller organizations and those that are more labor intensive are excluded. Furthermore, the burden of the property tax exemption falls on the local government, while the community benefits may be of much broader scope. These criticisms have been at the base of the current challenges to the property tax exemption.

A third justification examines the property tax exemption within a tax base framework. The main argument is that nonprofit property and income do not belong in the tax base. Nonprofit income is used to produce public goods and services and therefore it should not be treated as taxable income. The property tax exemption is harder to justify using the tax base approach because individual property not used for profit is also taxed. However, if the property tax is viewed as a proxy for an income tax on the imputed rental value of owner-occupied housing, then nonprofit property does not belong in the tax base (Heller, 1979 referenced in Brody, 2002). 
The question of whether the tax exemption does result in organizational behavior, such as providing services free or at reduced cost to low-income households, that would justify the tax exemption is certainly of importance. However, that topic is beyond the scope of our inquiry.

We start our discussion of the property tax exemption with a discussion of what we know about how the eligibility criteria for the property tax exemption differ across states and what we know about the magnitude of the tax benefit to nonprofits. We then turn to a discussion of the potential effects of the property tax exemption on the behavior of nonprofit providers and on the market competition between for-profits and nonprofit firms. In the final sections we consider efforts to remove the exemptions through legal action and through PILOTs (payments in lieu of taxes). We also include a somewhat related discussion of the growing trend for local governments to provide additional subsidies to nonprofit firms in order to encourage them to locate within the jurisdiction.

In essence, much of the research regarding differences in behavior between forprofits and non-profits treat the tax exemption as a zero-one dummy variable. This research simply compares the behavior or performance of nonprofit and for-profit firms. The difference in organizational form reflects the fact that nonprofits have tax exemptions. Our focus is not on the literature that simply compares for-profit and nonprofit firms. Rather, our focus is on how differences in the size of the tax exemptions affect behavior. Since property taxes and corporate income taxes are both taxes on capital (the property tax is a tax on the value of capital while the corporate income tax is a tax on the return to capital), we also consider research that addresses the effect of the 
corporate income tax exemption (but see Rushton (Chapter 21 of this book) for a more complete discussion of the deduction from the corporate income tax.)

\section{Eligibility Criteria for Property Tax Exemption}

States differ in the conditions that must be satisfied in order for a nonprofit organization to qualify for a property tax exemption. Bowman (2002) provides the most recent survey of these conditions, which are summarized in Table 1. These results synthesize provisions available in state constitutions and survey responses of state officials where the constitutions are not explicit about the particular criteria. Many of these criteria continue to undergo changes as exemptions are challenged by local governments and the courts develop more precise definitions and criteria for granting a property tax exemption.

Bowman finds that both ownership and use are necessary conditions to receive a property tax exemption. Thirty-nine states grant a property tax exemption to property that is both owned by a nonprofit and used for a charitable purpose. Only eleven states accept charitable use by itself as a sufficient condition for exemption, and no state would grant exemption just for nonprofit ownership. The original condition for charitable use specified that the property should be used "exclusively" for the exempt purposes (Bowman, 2002). However, this has changed over time to accommodate practices to lease some of the property to for-profit organizations, such as childcare centers in churches, gift-shops in hospitals, and other. In thirty-one states nonprofit and for-profit 
use is assessed separately, and taxes are paid only on the leased portion of the property used for profit. Sixteen states do not have rules for separate assessment, and practices vary about the extent to which the nonprofit pays property taxes. On the other hand, few nonprofits are exempt from property taxes when they rent space belonging to a for-profit entity. Only seventeen states exempt such property.

The definitions of nonprofit and charity used to determine eligibility for the property tax exemption vary widely across states and localities. The survey by Bowman reveals that thirty-six states require that the organization should be incorporated as a nonprofit (501 (c) (3)). However, nonprofit status is not a sufficient condition for property tax exemption. Forty-five states expect that the nonprofit organization would serve a charitable purpose. Charitable purpose is formally defined in only few states and the statutes provide diverse definitions about what constitutes charitable activity. The main criteria identified by Bowman from those statutes are public benefit, relieving government of a burden, relief of poverty, and income from donations. Using these criteria in his survey, Bowman finds that states use different combinations of these criteria as a way of identifying charitable purpose, as illustrated in the bottom half of Table 1.

Given the variety of statutes and practices, Bowman's study provides a good synthesis of the criteria used to determine eligibility for the property tax exemption. Another formidable task that remains is to understand how these criteria are applied in practice due to their vague definitions. Generally, broadly defined eligibility criteria are interpreted in favor of nonprofits, particularly when exemption challenges are taken to 
the courts. But there is no information about any patterns across states or different nonprofit organizations.

Second, as tax exemptions are challenged, there has been a move toward creating more specific requirements for each of the criteria, for example, defining charity care as a certain percentage spent on uncompensated care and community services by hospitals. Brody (2007) observes that lawsuits and legislation assert tighter definitions for exemption, establishing a widespread use of a "quid-pro-quo" rationale for granting exemption. Nonprofits are under pressure to quantify even the value of the intangible benefits they claim to provide that have been used to justify the property tax exemption. Again, much of this information is based on prominent cases, such as Utah County v. Intermountain Health Care Inc., and the 1997 Institutions of Purely Public Charity Act in Pennsylvania, both setting very specific requirements to be met for tax exemption purposes (Gallagher, 2002). The most comprehensive examination of legislative decisions on different challenges is presented in Brody (2007).

Further research is necessary to document these modifications in the exemption criteria in order to improve our understanding of their implementation, as well as implications about the future of the property tax exemption. Another line of potential research would focus on explaining the variations in eligibility across states. In addition, it would be of interest to determine how variations in eligibility criteria affect the number or magnitude of nonprofits that are eligible for a property tax exemption.

\section{Magnitude of the Revenue Loss from the Exemption}


One can consider the property tax exemption as an implicit subsidy, or a tax expenditure, to nonprofits. Instead of a property tax exemption, local governments could, at least in theory, provide direct subsidies to nonprofit organizations. ${ }^{1}$ Such direct subsidies would be determined through the budget process, and thus local governments would decide whether the size of the expenditure and the allocation across nonprofits were appropriate. For this reason, it would be desirable to know the value of this tax expenditure.

Given that nonprofits are not uniformly distributed across jurisdictions, a second policy issue that arises is how the "cost" of the implicit subsidy is distributed across jurisdictions. For example, universities benefit the entire state as well as out-of-state students, and some hospitals may benefit populations beyond the immediate locality, but the tax exemptions directly impact the local community. Krueckeberg (2004) discusses the unequal distribution of the property tax burden in New Jersey, and finds that the majority of tax exempt property is concentrated in 10 municipalities characterized by low income, high exemptions, and high effective property taxes.

There is no source that provides information about the value of the property tax exemption across all local governments. Nor is there a source that provides an annual report of the value of the exemptions for each state. Several factors peculiar to the nature of the property tax impede the estimation of the value of the exemption. First, exempt property is not necessarily assessed on a regular basis or with the care given to other property because tax assessors do not have any incentive to put effort into regular

\footnotetext{
${ }^{1}$ Local governments may not have legal authority to provide direct subsidies to nonprofit organizations. In some cases, such subsidies could be considered gifts or gratuities.
} 
assessment of property that will not be paying taxes. Lipman (2006a) reports that New York, Los Angeles, and San Diego spend equal effort on assessing taxable and exempt property, but that other big cities such as Chicago, Detroit, and San Antonio do not have sufficient staff to appraise exempt property. Other cities fall somewhere in between. Second, even if there are current property values for exempt nonprofits, it would still be necessary to apply property tax rates for each of the jurisdictions that would in the absence of the exemption levy a property tax on the property. While this is feasible for the area in which the researcher lives, gathering such information across a wide range of jurisdiction would be difficult.

There are periodic efforts to determine for specific jurisdiction the value of the property that is exempt. Many of those efforts are concentrated on a single city, region, or less frequently a state. For example, Lipman (2006b) reports the value of the property tax exemption for some of the biggest metropolitan areas. New York loses $\$ 605$ million annually and Boston $\$ 258$ million from the property tax exemption of nonprofit organizations. On the other hand, he estimates that Los Angeles loses only \$81 million and San Francisco $\$ 42$ million.

Cordes, Gantz, and Pollak (2002) provide estimates of the value of the property tax exemption for eight states that collect such data. The nonprofits in these states constitute about one-third of all nonprofits in the United States, and the total value of the exemption is estimated to be slightly higher than $\$ 3$ billion (Cordes et al, 2002, p. 91). They also find that charities nationally, excluding houses of worship, held about $\$ 500$ billion worth of property in 1997. With an average effective tax rate between 1.6 and 2.5 
percent, they estimate that the value of the property tax exemption nationally falls between $\$ 8$ and $\$ 13$ billion for 1997 (p. 89).

Gentry and Penrod (2000) estimate the magnitude of the benefit of exemptions from capital taxes for nonprofit hospitals. They find that the aggregate value of the property tax exemption in 1995 for nonprofit hospitals was $\$ 1.7$ billion. The value of the property tax exemption constituted 27 percent of total capital tax exemptions for nonprofit hospitals at all levels of government. Other estimates that we have come across are less informative because they consider only one local jurisdiction or only the value of property that can be subject to PILOTs.

In summary, little is known about the value of the property tax exemption and how the values of the exemption vary across jurisdictions. The absence of such measures is due to the absence of data, and in particular because actual tax rates and assessed values are not available for many local governments. First, collecting assessment data from each assessor is very time consuming. Further, if assessments are not available, it would be necessary to develop a methodology to measure the real estate value of tax exempt organizations. Second, any estimation of the forgone revenue will require a national database of effective tax rates.

If such data limitations are overcome, scholars can look at the value of the tax exemption and how it compares to the benefits that nonprofit organizations provide. Data about the forgone revenues from the property tax exemption can also be used by local governments to negotiate PILOT payments with nonprofit organizations. And, such data 
is necessary to study the effect of the property tax exemption on property ownership by nonprofits.

\section{Economic Effects of the Property Tax Exemption}

There are many possible economic effects that the property tax exemption might have on the behavior of nonprofits and on the "market" for the services provided by nonprofits In this section, we consider several economic decisions or market outcomes that might be affected by the property tax exemption.

Economic models of behavior assume purposeful behavior related to some goals such as profit or utility maximization. The challenges in modeling nonprofit behavior are related to the specification of the goals of nonprofits and the availability of data to test hypotheses derived from the models. There is not general agreement on what goals nonprofits seek or on how the nonprofit market achieves equilibrium. (For a detailed discussion of nonprofit models, see Chapter 10.) Furthermore, with a few exceptions tax exemptions have not been explicitly incorporated in the models of nonprofit behavior. We discuss extensions of the models that include the tax exemption, but they are based on economic assumptions about organizational behavior borrowed from for-profit organizations, and are subject to empirical verification.

\section{A. Use of the Financial Benefits of the Exemption}


One of the issues regarding capital tax exemptions concerns how nonprofits use this cost advantage. Steinberg (1991) lists three ways that nonprofits could apply the tax advantage. His discussion was in the context of nonprofits competing with for-profit firms, but the points apply to markets in which there are no for-profit firms, a situation that could be the result of the tax advantages enjoyed by nonprofits. Nonprofits could provide additional or higher quality goods and services or increase the quality of existing services. They could use the funds from the tax exemption to subsidize the price, and thus increase the quantity demanded. Second, nonprofits could use the tax exemption to provide goods that generate positive externalities. For example, Steinberg suggests that a nonprofit could provide excess capacity, for example more beds in a hospital, or provide price subsidies to low-income households. Third, nonprofits could use the benefits from the tax exemption to enable the nonprofit to use higher-cost production techniques, for example through managerial inattention or employee benefits.

It appears that there is some effort at trying to compare the costs of and the nature of the services provided by nonprofits to those of for-profit firms, particularly for hospitals, (see, for example, Hassett and Hubbard 1999; Norton and Staiger 1994; Sloan et al 2001; Kessler and McClellan 2002; Rose-Ackerman 1996)). But these studies focus on the effects of organizational form, i.e., nonprofit versus for profit. There are no efforts that we could identify to determine whether the magnitude of the tax exemption affects the cost structure or the nature of the services provided by nonprofits. No one has attempted to determine, for example, whether the differences between for-profit and nonprofit organizations in their cost structures, the nature of services they provide, or the 
types of clients they serve are smaller in communities with very low property tax rates or states with no corporate income tax. Or as Colombo (2006) asks in reviewing the Federal Trade Commission and Department of Justice 2004 report on competition in health care, "Is tax exemption, for example, 'buying' charity care for the poor, and would withdrawal of exemption negatively impact health care for the uninsured poor?"

\section{B. Decision to Own versus Rent}

In most states property is exempted from property taxes only if it is owned by the nonprofit and is used for purposes that make it eligible for a property tax exemption. Given that the property tax exemption reduces the cost of owning a building, it would be expected that the exemption would influence a nonprofit's decision to own versus rent space, assuming that nonprofits made such a decision based on economic grounds, i.e., a desire to minimize costs. Cordes, Gantz, and Pollak (2002) present the theory behind such a decision. The rental or user cost per dollar for a for-profit landlord is given by the following equation

$$
\mathrm{c} / \mathrm{q}=\mathrm{r}+\delta(1-\mathrm{t} \alpha) /(1-\mathrm{t})+\tau
$$

where $\mathrm{c}$ is the gross market rent charged per dollar invested, $\mathrm{q}$ is the value of the property, $\mathrm{r}$ is the before tax cost of capital, $\delta$ is the economic depreciation rate, $\mathrm{t}$ is the tax 
rate, $\alpha$ is the percent of depreciation that can be claimed for income tax purposes, and $\tau$ is the property tax rate.

If the nonprofit owned the building then

$$
\mathrm{c}^{*} / \mathrm{q}=\mathrm{r}+\delta
$$

It would be better to own than rent if $\mathrm{c} / \mathrm{q}-\mathrm{c} * / \mathrm{q}>0$, or if

$$
\tau-\delta \mathrm{t}(\alpha-1) /(1-\mathrm{t})>0
$$

If $\alpha=1$, i.e., tax depreciation was equal to economic depreciation, then the nonprofit would save by owning. But as $\alpha$ increases, the second term gets larger. Thus, if for-profit firms are allowed significantly accelerated depreciation, i.e., if $\alpha$ is very large, then the nonprofit would be better off renting. When $\alpha$ is very large, the depreciation allowance provides a substantial tax subsidy to the for-profit landlord. When the federal government in the early 1980s adopted accelerated depreciation for buildings, there were examples of nonprofit organizations selling buildings to for-profit firms and then leasing the building back.

As best we can determine, there are no papers that have investigated whether the size of the property tax exemption increased the likelihood that a nonprofit will own rather than rent. There are challenges to conducting such a study. First, the decision of a nonprofit to own may be driven by considerations other than cost minimization. For 
example, it may be feasible to successfully conduct a capital drive to build or buy a building while generating contribution to cover overhead such as rent may be more difficult. Thus, a nonprofit may decide to own even when it is not consistent with cost minimization. Second, to conduct such a study requires consideration of nonprofits that face different tax rates, i.e., the sample must contain nonprofits from multiple jurisdictions. Third, it would be necessary to gather data to control for other factors that might affect the decision to own rather than rent.

\section{Location Decision}

The property tax exemption should eliminate the property tax as a consideration in the location decision of nonprofit organizations that own their own building. Thus, for example, the property tax exemption would make the location in downtown areas more affordable for nonprofits that own property. On the other hand, nonprofit organizations that rent face the same rental rates as for-profit organizations, unless there is a different assessment of property leased to nonprofit organizations.

Nonprofit location theory has not considered the property tax exemption, but has focused on other factors that determine the location choice of nonprofit organizations. For example, Wolpert, Naphtali, and Seley (2001) study the spatial patterns of nonprofit location in New York. Among those nonprofits, the type and scale of services provided by the organization requires that some nonprofits are located in a central location, such as museums and arts organizations, while hospitals and daycare centers may be more 
dispersed. Also, nonprofits that benefit particular populations, such as homeless shelters, soup kitchens, and job training centers, would be located close to them to ensure proper service access. Other nonprofit organizations may prefer to be located together with other similar organizations to benefit from economies of agglomeration and a common pool of skilled labor force. Habitat for Humanity moved its headquarters to Atlanta for similar reasons. Finally, nonprofit organizations that have been established for a long time tend to be located in the central parts of the city. In that aspect, the property tax exemption is keeping their current location more affordable regardless of changes in property values, at least in terms of out-of-pocket cost; nonprofits would still face the opportunity cost of owning expensive land. But perhaps nonprofits do not consider such opportunity costs in making these location decisions.

Bielefeld and Murdoch (2004) compare the location patterns of nonprofit and forprofit providers of education and human services in six metropolitan areas. They find that similar nonprofits were clustered and their location was best explained by the needs and resources of the community. Additionally, some nonprofits were located in proximity to similar nonprofits or similar for-profits, indicating agglomeration factors.

In addition to the intra-metropolitan location decision, nonprofits also make intermetropolitan or inter-state location decision. There are substantial differences in the number of nonprofits per capita across the country (Weisbrod, 1988). Nonprofits are usually concentrated in major cities, but some smaller cities may also have a disproportionate number of nonprofit organizations relative to their tax bases. Gentry and Penrod (2000) find that the distribution of nonprofit hospitals varies widely across 
the United States. Nonprofit hospitals dominate in the Northeast, where there are almost no for-profit hospitals. About half of the for-profit hospitals are concentrated in three states: Texas, Florida, and California. But neither they nor anyone else that we could determine have considered the extent to which the location pattern is due to differences in property and state corporate income tax exemptions, or even if the spatial pattern is a result of location decisions rather than a decision regarding organization form, nonprofit versus for-profit.

There is a literature that considers the optimal location of public service sites (see for example, White (1979). This literature might be the basis for a theory of the optimal location of nonprofit sites in the presence of property tax exemptions. Such a theory would be necessary in order to specify any empirical work other than some ad hoc empirical model of location.

\section{Capital-Labor Ratio, Capital-Land Ratio, and the Size of Operation}

For for-profit firms, it would be expected that exemption from taxes on capital, such as the federal and state corporate income taxes and property taxes, would increase the ratio of capital to labor used in production because the cost of capital would be reduced, and would increase the level of output since average costs would be lower. But we have not found any theoretical models of nonprofit behavior that consider these issues. Whether we would find such an effect for a nonprofit organization would likely depend on the organization's behavioral objectives. For example, consider Newhouse's (1970) 
economic model of a hospital. In his model the decision maker maximizes utility, which is a function of the quantity of services provided and the quality of those services. Such a hospital could choose to provide higher quality services than would a for-profit hospital. If higher quality is associated with higher labor per unit of output, then the nonprofit hospital will have a lower capital labor ratio and less output than a for-profit hospital.

Various authors have compared the size of for-profit hospitals to the size of nonprofit hospitals. Gentry and Penrod (2000), for example, report that in 1995, while 59 percent of short-term hospitals were nonprofit, they accounted for 70 percent of the beds. In part, this is because nonprofits include some very large teaching hospitals.

Gentry and Penrod also provide data on the capital intensity of hospitals. They report that at the median of their distributions nonprofit hospitals have higher total wages relative to fixed assets and lower capital costs relative to total cost than do for-profit hospitals. This suggests that nonprofit hospitals are less capital intensive than for-profit hospitals. This is consistent with the simple extension of Newhouse's model presented above. However, this result could also be due to the mix of the particular services provided by nonprofit hospitals as compared to for-profit hospitals. Gentry and Penrod did not conduct an empirical investigation of the relationship between capital tax exemptions and capital intensity.

David (2005) examines the dynamics of hospital convergence in size overtime between nonprofit and for-profit hospitals. In 1960, nonprofit hospitals maintained on average three times as many beds per hospital as for-profit hospitals. By 2000, the average nonprofit hospital was only 30 percent larger than a for-profit hospital. The main 
sources of convergence are: 1) different growth in scale by for-profit (5 percent) and nonprofit (2.3 percent) hospitals up to 1980 s, and 2) negative growth by nonprofit hospitals due to the introduction of the Prospective Payment System (fixed reimbursement on the basis of the number of patients, not on reported costs) combined with positive (modest) growth of for-profit hospitals.

David (2005) models the factors that affect the ratio of nonprofit to for-profit hospitals and their size. The decision to select one organizational form over the other depends on the cost advantages of nonprofit status (tax exemptions), and the nondistribution constraint (profits should be invested in the charitable mission of the organization). With the advantage of tax exemptions, nonprofit hospitals are expected to have higher output. However, assuming that nonprofit owners can convert some of their cost advantage into perks, and that they have the same utility from perks as for-profit owners from profits, the output will depend on the ability of nonprofits to convert their cost advantage into perks. The convergence in size depends on demographic factors, changes in cost advantages, and availability of government beds. Nonprofit and forprofit hospitals converge in size when the cost advantages of nonprofit hospitals decrease, when government beds decrease, and when demand for services increases (David, 2005, pp. 23-24).

We were unable to find any study that considered the capital intensity of nonprofit organizations in non-hospital markets or any studies that investigated the effect of the tax exemption on the size of the organization. To conduct good empirical research, it is 
necessary to have a theory of how the exemption from capital taxes will affect the capital-labor ratio and agency size. In addition, obtaining adequate data is a challenge.

Since the property tax applies to both land and capital, a property tax exemption should not affect the capital-land ratio. But, we did not identify any study of the effect on the capital-land ratio. Casual empiricism suggests that there are nonprofits such as some private colleges and universities and churches that have very large land holdings, contrary to the expectation of economic theory that the property tax exemption should not affect capital-land ratio. It could be that the nonprofits are able to hold these lands because the property tax exemption eliminates any cash flow payment, or that for these nonprofits, land is a more important input than for other organizations.

\section{E. Nonprofit Share of the Market}

The property tax exemption is an implicit subsidy to nonprofit organizations that could increase the size of the nonprofit sector over what it would be in the absence of the exemption. We are unaware of any research that has studied this effect. However, in those markets that contain both nonprofit and for-profit organizations, the property tax exemption could be a factor that explains the nonprofit market share of that industry. We have identified three papers that consider the effect of property taxes on nonprofit market share and three papers that consider the change in the form of organization over time.

Hansmann (1987) considered four markets: short-term hospitals, nursing homes, post-secondary vocational education and primary and secondary education. Using 1975 
data for the 50 states, he finds that the statewide weighted average effective property tax rate is positive for all four markets, but statistically significant at the 10 percent level or better only for post-secondary vocational education. He also uses data for the largest city in each state, but obtains no statistically significant coefficients. Nonprofit market share is measured as the number of beds for hospitals and nursing homes, enrollment for vocational schools, and number of nonprofit firms (excluding religious schools) for primary and secondary education. He also includes the state corporate income tax rates. Since both the property tax and the corporate income tax are taxes on capital, one should expect similar effects for the two taxes. However, the coefficients on the corporate tax rate are positive and, unlike the coefficients on the property tax rate, the coefficients on the state corporate income tax are generally significant.

Chang and Tuckman (1990) consider hospitals in Tennessee, using county level data for 1982-85. Chang and Tuckman note that many counties have no hospital or only one hospital. They investigate whether the nonprofit share of the hospital market, as measured by patient days, increases with the effective property tax, but contrary to expectations, the coefficient is negative and significant. They do find, as expected that higher property tax rate increases the probability that a county has only one hospital.

Gulley and Santerre (1993) use a five-year increment panel (1967-1987) for all 50 states plus DC to consider the effect of higher property taxes on the nonprofit market share of hospitals, measured by the number of beds. Unlike Hansmann, and Chang and Tuckman, Gulley and Santerre consider government hospitals as well. The other two papers treat government hospitals as fixed in supply, while Gulley and Santerre assume 
the government share is endogenous. Thus, they estimate three equations, with the dependent variables being the shares for the nonprofit, for-profit and government hospitals, incorporating the condition that the share must sum to one. They find that the weighted statewide average effective property tax rate and the state corporate income tax rate have positive and statistically significant affect on the nonprofit market share. The coefficients for the for-profit share equation are negative, as expected, but statistically significant only for the corporate income tax. The elasticity of nonprofit market share with respect to the property tax rate is 0.041 , which seems to be rather small.

We identified two papers that consider the effect of just the corporate income tax on nonprofit market share of hospitals. Mullner and Hadley (1984) find that changes in state corporate income tax rates between 1972 and 1983 had no statistically significant effect on the change in for-profit market share. Hu (2006) considers both national 35year time series data and longitudinal data (all 50 states plus DC for 1975-2000) to investigate the effect of the corporate income tax exemption on nonprofit share of the hospital market, measured separately by beds and admissions. He finds that the larger the corporate income tax rate, the larger the nonprofit market share of the hospital market. Related to market share is the effect of the tax exemptions on the magnitude of the commercial activities of nonprofit organizations (see Chapter 21 for a discussion of unrelated business income tax). Cordes and Weisbrod (1998) consider how the property tax and corporate income tax exemptions affect commercial activities. As dependent variables they use commercial share measured as program service revenue as a share of total revenue and whether the nonprofit filed an unrelated business income tax (UBIT) 
return. The UBIT is a tax on revenues earned from activities not directly related to the charitable mission of the organization. They created two dummy variables, one for whether a state had high property taxes and one for whether the state had high corporate income taxes. Using the 1992 public use sample of IRS Form-990 returns, they find that higher property taxes and higher corporate income taxes are associated with higher commercial share. The probability of filing a UBIT return is positively related with higher corporate income taxes.

The share of the market held by nonprofits will depend on entry into and exit from the industry by nonprofit and for-profit firms, i.e., it will depend on market equilibrium. Suppose that the market is competitive and nonprofit and for-profit firms take the price as given and pick the quantity to provide. Since nonprofit firms have a cost advantage because of the tax exemption, their share of the market will increase, perhaps to 100 percent. One can envision that market structures other than perfect competition and alternative nonprofit behavioral objectives would yield alternative market equilibria.

Additional empirical research on market share should be conducted, particularly for non-hospital markets. However, attempting to measure market share for other services is a challenge. Additional theoretical work is needed to explain market dynamics. Furthermore, the empirical work has been focused on explaining existing market share, but empirical research also needs to consider the entry/exit process and how the magnitude of the tax exemption affects that process.

\section{F. Choice Between For-profit and Nonprofit Status}


Clearly related to the nonprofit share of an industry is the effect of the property tax exemption on the decision to organize as a for-profit or a nonprofit firm. There are some theoretical discussions of this choice. Glaeser and Shleifer (2001) develop a model in which an entrepreneur chooses a nonprofit status as a means of committing to soft incentives. They argue that tax exemptions are not relevant to this decision. On the other hand, Lakdawalla and Philipson (2006) develop a model of organizational choice and derive equilibrium conditions, where the marginal firm determines how the industry is split between for-profit and nonprofit firms. Within their model they show that an increase in the tax advantage of nonprofits (i.e., a reduction in the production cost of nonprofits) will increase the share of nonprofits in the industry.

\section{G. Property Value}

The property tax exemption combined with the fact that nonprofits use land within a jurisdiction, means that local governments obtain less revenue than they would from other uses of the property. Does this loss of government revenue get capitalized into the value of property within the jurisdiction?

Theoretically, the effect of nonprofits on housing values is ambiguous. On the one hand, more nonprofits would decrease the property tax base for the local government and it would have to increase taxes for residents, which would lower property values. On 
the other hand, the presence and services of a nonprofit organization may increase the appeal of the area, thereby raising property values.

There are a number of studies that have investigated the effect that specific nonprofits or types of nonprofits have on housing prices in the area surrounding the nonprofit. For example, Bielefeld et al (2006) used a hedonic equation to determine the effect on housing prices of a nonprofit that was located within one mile of the house. Dummy variables for the number of different types of nonprofits in one-mile radius are used to capture the effect of their presence on housing prices. Overall, the presence of a nonprofit within a one-mile radius increases the house sale price. However, the effect varies by the type of nonprofit and the number of nonprofit organizations. Arts, animal, and environmental nonprofits have initially negative and then positive effect as the number of organizations increases. Health, religion and education nonprofits have a positive effect. Human services nonprofits have a negative effect at any number of organizations.

The findings by Bielefeld are in line with earlier studies. Ottensmann (2000) examined the effect of church proximity on housing values and rent and found a significant positive effect. Ellen and Voicu (2006) find that housing redevelopment by both nonprofit and for-profit organizations increased the value of neighboring houses. Nonprofits invested in more distressed areas and their impact remained stable over time, lending support to the idea that nonprofits are more committed to social services characterized by externalities than for-profits. 
However, these studies consider the effect on housing prices within one jurisdiction, for example Bielefeld et al (2006) used housing data for Indianapolis, Indiana. Using data for one jurisdiction does not allow for variations in property tax rates due to differences in the importance of nonprofits. To conduct a study to determine whether the property tax exemption was capitalized into house values would require a data set that would be very hard to construct. In particular, it would be necessary to quantify for several jurisdictions the magnitude of the property tax revenue that would have to be replaced and the thus the necessary increase in the property tax rate.

\section{PILOTs and Efforts to Revoke Tax-Exempt Status}

The property tax provides a substantial portion of local government revenues. However, its visibility has made it the most unpopular tax among tax payers. A tax revolt starting with Proposition 13 in California has brought significant restrictions on the revenues that can be raised through property taxes. Furthermore, local governments are facing other fiscal pressures such as cyclical variations in transfers from the federal and state government, and structural constraints due to rising wage and benefits obligations. Therefore, cash-strapped cities have looked for other revenue options. An option that has been subject to a lot of media attention are payments-in-lieu-of-taxes or PILOTs. These are agreements between the local government and major nonprofit organizations on payments to compensate the local government for services provided to nonprofit organizations. The tension associated with this practice is illustrated by the fact that 
governments refer to PILOTs as voluntary agreements, while nonprofits consider them essentially blackmail backed up by threats to revoke their property tax exemption. Arrangements for PILOTs have existed for many years but have been concentrated among a few cities with large universities such as Harvard, MIT, and Boston College. However, the recent fiscal pressures have forced other governments to consider PILOTs, particularly for educational institutions and hospitals with sizeable endowments and property. A study conducted for North Carolina nonprofits identifies the main factors increasing the probability for challenges to the tax exempt status of nonprofits (Anderson et al., 2003). The first set of factors is related to the fiscal environment of the local government. Large and frequent budget shortfalls, as well as a considerable concentration of nonprofit organizations within a locality are more likely to lead to challenges of the nonprofit tax exemption. The second set of factors is related to the characteristics of the nonprofit organizations. Nonprofits with large assets and land are more likely to be scrutinized for their exemption, as well as those competing with forprofit companies and generating a significant amount of their revenues through service fees. Barniv, Danvers, and Healy-Burress (2005) also consider the loss of property tax exemptions among nonprofit hospitals. They find that the larger the tax base of a nonprofit hospital, the greater the likelihood of revoking the tax-exempt status.

The most comprehensive study of the use of PILOTs so far is by Leland (2002), who surveyed the largest cities in the United States. Only seven of the fifty-one large cities surveyed report that they collect PILOT payments from nonprofit organizations, ranging from as low as $\$ 260,000$ in Minneapolis to $\$ 19,400,000$ in Boston (Leland, 2002, 
p. 202). As a percentage of the annual city budget, these revenues range between 0.03 percent and 1.4 percent respectively. While these findings indicate that among large cities PILOTs are not a significant revenue choice, there is no such comprehensive information about the extent of PILOT programs in smaller cities. Leland also finds that the main factors contributing to the introduction of PILOT programs are municipal revenue needs, nonprofit competition with for-profits, and large revenues from services. Brody (2007) also reports that PILOTs are sought from organizations that generate revenues from services and they can be interpreted as attempts to tax non-local beneficiaries of the services.

We do not know whether and how challenges to the tax exemptions and PILOTs influence service levels, financial performance, or the location decisions of nonprofits. Nonprofits argue that any payments to local governments would divert much needed resources from the pursuit of their missions or would require additional fundraising to compensate for the lost resources. The extent of these impacts has not been established empirically.

However, PILOTs have many disadvantages. They generate some much needed revenue for local governments, but considering their ad-hoc and short-term nature, as well as the conflict associated with any arrangement, they do not appear to hold the key to resolving long-term issues. Another more transparent and predictable tool for compensation for provided services is fees for services. There has been a general increase in the use of fees by local governments. However, the extent to which nonprofits contribute to some of these fees is not clear. 
Future research on PILOTs should focus on understanding the extent of their use, the stability of the revenue generated from such arrangements, the costs to local governments of implementing them, and the cost to nonprofit organizations in terms of revenue that can be used for community services. Another interesting question is whether nonprofit organizations can shift the cost of PILOTs or fees to their customers, and therefore distribute across localities the burden of the tax exemption. The main obstacle in the current research has been the availability of data, particularly data beyond the case studies frequently discussed in reports.

\section{Direct Subsidies by Local Governments}

In addition to the implicit subsidy provided by the property tax exemption, local governments have provided discretionary subsidies to nonprofit organizations in order to influence their location decision. There is no systematic account of the extent of those subsidies but they are illustrated by several relocation examples from the media. Bixler (2006) in the Atlanta Journal Constitution reports that the City of Atlanta provided some financial incentives to Habitat for Humanity for its move of part of its headquarter operation from Plains, Georgia to Atlanta. The American Cancer Society was provided with incentive financed by a local foundation to locate in downtown Atlanta (Saporta and Woods 2006). In 2006, Orlando, Florida won a bid to attract a nonprofit medical research institute with a $\$ 310$ million incentive package (Hundley 2006). A similar incentive package, including donated land, was put together for a medical research center 
affiliated with Ohio State University in Columbus, Ohio (Pramik, 2005). And, Orlando provided 165 acres of land, for free, to the Campus Crusade for Christ in exchange for establishing its World Center for Discipleship and Evangelism in Orlando (Allman 2007). Government incentives include land donations, infrastructure improvements around new developments, and packages to cover relocation costs.

These examples appear to contradict the story that was told so far, one of tension between local government and nonprofit organizations over the forgone revenues from property taxes. However, they highlight the nature of the issues underlying the property tax exemption - that nonprofit organizations benefit the community with their activity and exemption and subsidies are necessary to sustain such activity. Future research might attempt to catalogue instances of local governments providing economic incentives to nonprofits to locate in the jurisdiction. It would also be of interest to determine what factors are associated with a decision to provide an incentive, for example, whether local governments that offer such direct subsidies have different revenue patterns than those challenging nonprofit exemptions.

\section{Conclusion: Why it matters and to whom - the relative importance of expanding our knowledge to practitioners, policy-makers, and scholars}

The property tax is a significant revenue source for local governments that over time has been gradually eroded by popular tax revolts. At the same time, the nonprofit sector has become key in the provision of public goods and services, and tax exemptions are defended as appropriate subsidies for these activities. However, the link between the 
beneficiaries of the services and their location has become less obvious as technological advances have decreased the importance of physical distance. As a result of all these changes, the property tax exemption has been an issue of interest to local governments, nonprofit organizations, and scholars for quite some time and will continue to be an important policy issue.

There are significant theoretical and empirical gaps to be addressed by future research. Policy makers need to know more about the revenues forgone from the exemption, about the advantages and disadvantages of PILOTs and other solutions for distributing more evenly the burden of the property tax exemption. Scholars need to improve their understanding of the economic effects of the property tax exemption by examining further the behavior of nonprofit organizations, both theoretically and empirically. It is not clear to what extent differences in property taxes determine the mix of for-profit and nonprofit organizations, and the quantity and quality of services produced by nonprofit organizations. Furthermore, broadly defined exemption criteria may result in different treatment of otherwise similar organizations, but the extent of this has not been documented yet. 


\section{References}

Allman, T.D. 2007. “The Theme-Parking, Megachurching, Franching, Exurbing, McMansioning of America: How Walt Disney Changed Everything." National Geographic 211(3):97-115.

Anderson, Dave, Joel Dunn, Megan Fotheringham, Eva Gao, Tim Greeff, and Sandra Johnson. 2003. The Status of Nonprofit Property Tax Exemption in the State of North Carolina. Report. Terry Sanford Institute of Public Policy, Duke University. http://www.pubpol.duke.edu/research/students/spring2003-01.pdf

Bielefeld, Wolfgang, and James C. Murdoch. 2004. “The Locations of Nonprofit Organizations and Their For-Profit Counterparts: An Exploratory Analysis." Nonprofit and Voluntary Sector Quarterly, Vol. 33 (2): pp. 221-246

Bielefeld, Wolfgang, Seth Payton, John Ottensmann, Wendy McLaughlin, and Joyce Man. 2006. The Location of Nonprofit Organizations Influences Residential Housing Prices: A Study in Marion County, Indiana. Indianapolis, IN: Center for Urban Policy and the Environment, School of Public and Environmental Affairs, Indiana University-Purdue University Indianapolis.

Bixler, Mark. 2006. "Habitat for Humanity Moves to Atlanta.” Atlanta JournalConstitution April 20, 2006: 1D

Bowman, Woods. 2002. “The Institutional Property Tax Exemption.” Paper prepared for the Lincoln Institute of Land Policy and presented at the 2002 Conference of the Association for Research on Nonprofit Organizations and Voluntary Action, Montreal, Quebec. 
Brody, Evelyn. 2002. "Legal Theories of Tax Exemption: A Sovereignty Perspective.” In Evelyn Brody (ed), Property-Tax Exemptions for Charities, Washington, DC: The Urban Institute Press, pp 145-172.

Brody, Evelyn. 2007. “The States' Growing Use of a Quid-Pro-Quo Rationale for the Charity Property Tax Exemption.” The Exempt Organization Tax Review, June 2007, pp. 269

Chang, Cyril F. and Howard P. Tuckman. 1990. "Do Higher Property Tax Rates Increase the Market Share of Nonprofit Hospitals?" National Tax Journal 43(2): 175-187.

Colombo, John D. 2006. "The Role of Tax Exemption in a Competitive Health Care Market.” Journal of Health Politics, Policy and Law 31(3):623-642.

Cordes, Joseph J., Marie Gantz, and Thomas Pollak. 2002. "What Is the Property-Tax Exemption Worth.” In Evelyn Brody (ed), Property-Tax Exemptions for Charities, Washington, DC: The Urban Institute Press, pp 81-112.

Cordes, Joseph J. and Burton A. Weisbrod. 1998. "Differential Taxation of Nonprofits and the Commercialization of Nonprofit Revenues." Journal of Public Analysis and Management 17(2): 195-214.

David, Guy. 2005."The Convergence between For-Profit and Nonprofit Hospitals in the United States.” Paper presented at the 2006 American Economic Association Meeting. http://www.aeaweb.org/annual_mtg_papers/2006/0106_0800_0204.pdf

Ellen, Ingrid Gould, and Ioan Voicu. 2006. "Nonprofit Housing and Neighborhood Spillovers" Journal of Policy Analysis and Management 25(1): 31-52.

Gallagher, Janne. 2002. “The Legal Structure of Property Tax Exemption.” In Evelyn 
Brody (ed), Property-Tax Exemptions for Charities, Washington, DC: The Urban Institute Press, pp 3-22.

Gentry, William M. and John R. Penrod. 2000. "The Tax Benefits of Not-for-Profit Hospitals" in David M. Culter (ed) The Changing Hospital Industry: Comparing Not-for-Profit and For-Profit Institutions, Chicago, IL: University of Chicago Press, pp 285-324.

Glaeser, Edward L. and Andrei Shleifer. 2001. "Not-for-profit Entrepreneurs." Journal of Public Economics 81(1): 99-115.

Gulley, David O. and Rexford E. Santerre. 1993, "The Effect of Tax Exemption on the Market Share of Nonprofit Hospitals.” National Tax Journal 46(4): 477-486.

Hansmann, Henry. 1987. "The Effect of Tax Exemption and Other Factors on the Market Share of Nonprofit Versus For-Profit Firms." National Tax Journal 40(1): 71-82.

Hassett, Kevin A. and R. Glenn Hubbard, 2000. "Noncontractible Quality and Organization Form in the U.S. Hospital Industry.” Mimeo

Hu, Zhenhua. 2006. Two Essays on Corporate Income Taxes and Organizational Forms in the United States. Ph.D. Dissertation. Georgia State University and Georgia Institute of Technology.

Hundley, Kris. 2006. “Orlando Wins Biotech Plum.” St. Petersburg Times, August 24, 2006: 1D

Kessler, Daniel P. and Mark B. McClellan. 2002. "The Effects of Hospital Ownership on Medical Productivity." RAND Journal of Economics 33 (3): 488-506.

Krueckeberg, Donald A. 2004. "Free New Jersey: The Burden of Property Tax 
Exemptions." Report.

http://www.njleg.state.nj.us/PropertyTaxSession/OPI/free_new_jersey.pdf

Lakdawalla, Darius and Tomas Philipson. 2006. "The Nonprofit Sector and Industry Performance.” Journal of Public Economics 90(9): 1681-1698.

Leland, Pamela. 2002. "PILOTs: The Large-City Experience." In Evelyn Brody (ed), Property-Tax Exemptions for Charities, Washington, DC: The Urban Institute Press, pp 193-210.

Lipman, Harvey. 2006a. "Cities Take Many Approaches to Valuing Tax-Exempt Property." Chronicle of Philanthropy, Vol. 19 (4): p. 14

Lipman, Harvey. 2006b. "The Value of a Tax Break." Chronicle of Philanthropy, Vol. 19 (4): p. 13

Mullner, Ross and Jack Hadley. 1984. "Interstate Variations in the Growth of ChainOwned Proprietary Hospitals, 1973-1982." Inquiry (Summer): 144-151.

Newhouse, Joseph P. “Toward a Theory of Nonprofit Institutions: An Economic Model of a Hospital.” American Economic Review 60 (1): 64-74.

Norton, Edward C. and Douglas O. Staiger. 1994. "How Hospital Ownership Affects Access to Care for the Uninsured." RAND Journal of Economics 25: 171-185.

Ottensmann, John R. 2000. Catholic Diocese of Cleveland: Economic Value of Selected Activities. Indianapolis, IN: Indiana University-Perdue University Indianapolis, School of Public and Environmental Affairs, Center for Urban Policy and the Environment.

Pramik, Mike. 2005. “OSU Likes Dublin Site for Medical Enterprise.” The Columbus 
Dispatch, September 9, 2005: 1E.

Rose-Ackerman, Susan. 1006. "Altruism, Nonprofits, and Economic Theory.” Journal of Economic Literature 34 (2: 701-728.

Saporta, Maria, and Walter Woods. 2006. "Cancer Society to Relocate.” Atlanta JournalConstitution August 9, 2006: 1B.

Sloan, Frank A., Gabriel A. Picone, Donald H. Taylor Jr., and Shin-Yi Chou. 2001. "Hospital Ownership and Cost and Quality of Care: Is There a Dime's Worth of Difference." Journal of Health Economics Vol. 20 (1): pp. 1-21.

Steinberg, Richard. 1991. "Unfair' Competition by Nonprofits and Tax Policy." National Tax Journal 44(3):351-364.

Weisbrod, Burton A. 1988. The Nonprofit Economy. Cambridge, MA: Harvard University Press.

White, Andrew N. 1979. "Accessibility and Public Facility Location.” Economic Geography 55(1): 18-35.

Wolpert, Julian, Zvia Naphtali and John Seley. 2001. "The Location of Nonprofit Facilities in Urban Areas." Lincoln Institute of Land Policy Working Paper. http://www.lincolninst.edu/pubs/dl/111 WolpertNaphtaliSeley01.pdf 
Table 1. Criteria for Exemption of Nonprofit Organizations

\begin{tabular}{|l|l|l|}
\hline Ownership vs. Use & & \\
\hline Nonprofit ownership only & no states & \\
\hline Exempt use only & 11 states & AR, CT, GA, IA, MS, NV, NH, NM, OH, OK, WV \\
\hline Nonprofit ownership and exempt use & 39 states & all except the states identified above \\
\hline Property leased to a nonprofit is exempt & 17 states & AK, AR, HI, IA, ID, LA, MA, MD, MN,MT, NM, NV, OK, OR, RI, SC, UT \\
\hline Property leased to a nonprofit is not exempt & 31 states & $\begin{array}{l}\text { AL, AZ, CA, CO, CT, DE, FL, GA, IL, KS, KY, ME, MI, MS, MO, NE, NH, } \\
\text { NJ, NY, NC, ND, OH, PA, SD, TX, VT, VA, WA, WV, WI, WY }\end{array}$ \\
\hline $\begin{array}{l}\text { Nonprofit property leased to a for-profit } \\
\text { organization is assessed separately }\end{array}$ & 31 states & $\begin{array}{l}\text { AK, AR, CO, CT, DE, FL, HI, IA, IN, KY, LA, MA, ME, MI, MO, MT, NC, } \\
\text { ND, NE, NJ, NH, NM, NY, OR, PA, SC, SD, TX, UT, VA, WI }\end{array}$ \\
\hline Property is not split, assessment varies by states & 16 states & AL, AR, CA, GA, ID, KS, MD, MS, NV, OH, OK, TN, VT, WA, WV, WY \\
\hline & & \\
\hline $\begin{array}{l}\text { Definition of charity used to grant } \\
\text { exemption status }\end{array}$ & & \\
\hline Organized as nonprofit corporation & yes: 36 states & \\
\hline & no: 7 states & \\
\hline Pursue charitable purpose & yes: 45 states & \\
\hline & no: 1 state & \\
\hline Relieve government of burden & yes: 19 states & \\
\hline & no: 21 states & \\
\hline Derive most of its income from donations & yes: 14 states & \\
\hline & no: 23 states & \\
\hline Provide public benefit & yes: 38 states & \\
\hline & no: 7 states & \\
\hline Donate a substantial portion of its services & yes: 15 states & \\
\hline & no: 22 states & \\
\hline Provide services to all & yes: 24 states & \\
\hline & no: 13 states & \\
\hline Source: Bowman (2002) & & \\
\hline
\end{tabular}

Source: Bowman (2002) 